Article

\title{
Environmental Management System Adoption and the Operational Performance of Firm in the Textile and Apparel Industry of China
}

\author{
Biao $\mathrm{Li}^{1}$ and Kekun $\mathrm{Wu}^{1,2, *}$ \\ 1 School of Finance/MBA School, Zhongnan University of Economics and Law, No. 182 Nanhu Avenue, \\ East Lake High-Tech Development Zone, Wuhan 430073, China; jackleeb@163.com \\ 2 Academy of Mathematics and Systems Science, Chinese Academy of Sciences, \\ No. 55 Zhongguancun East Road, Haidian District, Beijing 100190, China \\ * Correspondence: kkwu@zuel.edu.cn; Tel.: +86-27-8838-6770
}

Received: 24 April 2017; Accepted: 7 June 2017; Published: 9 June 2017

\begin{abstract}
In China, more firms in the textile and apparel industry adopt environmental management systems compared to firms that manufacture other products. It is important to know how the firms' financial and real performances are affected. We study the changes of firms' performance in profitability, sales, and operational efficiency after environmental management system (EMS) adoption using an event study. Based on 22 events of EMS adoption, we found a significant decrease in firms' profitability, sales, and inventory productivity. We explore the reasons which led to the decrease in firm performances. We found that the increase in sample firms' total assets is the major reason. The loss in operational efficiency and flexibility are due to the requirements of the EMS.
\end{abstract}

Keywords: social sustainable performance; operations; event study; textile and apparel industry

\section{Introduction}

Being green brings both opportunities and challenges to textile and apparel firms. On the one hand, it helps firms to shape better public image and attract more consumers. On the other hand, being green involves an investment in clean technologies, adapting to environmentally-friendly manufacturing systems, etc. It remains a problem to determine if it pays to be green [1,2]. We analyze the impacts of the adoption of environmental management systems (EMS) on the firms' financial and operational performance. We test the abnormal value of changes in sales, total assets, operating incomes, return on asset (ROA), return on sales (ROS), sales over asset (SOA), and inventory turnover during the period when firms start to formally implement EMS. Our results show that the adoption of EMS led to decreases in sales, SOA, inventory turnover, and increases in total asset.

We restrict ourselves to a sample of Chinese textile and apparel firms. As Chen and Burns [3] state, the textile wet processing process causes adverse environmental impacts due to the use of dyes and other chemicals. China is an important player in the global textile and apparel value chain. According to the latest census data, over $13.18 \%$ of manufacturing firms in China produce textile and apparel-related products. The population of employees working in the industry exceeds 12.5 million [4]. China was on the top of the ranking for exporters of textiles and clothing in 2015 [5]. However, Chinese firms are usually at the end of the textile and apparel value chain. Ma et al. [6] mention that although some apparel brands relocated their manufacturing facilities to other countries, the production processes which result in pollution remains in China. In the last decade, China has faced very serious environment problem. The Chinese people are becoming aware of the harmfulness of pollution in the air and water. Environment and sustainability are attracting more attention from the public. Many firms have been forced to transfer to environmentally-friendly management systems by their supply chain partner, or the environmental authorities. 
Sustainability is becoming popular in operations management $[7,8]$. A few papers have analyzed the sustainable operations of firms in the textile and apparel industry. Shen [9] studies the sustainable supply chain practice of H\&M. Based on secondary data, he analyzes the relationship between supply chain decisions and the sustainability considerations of H\&M. Motivated by the real practices in the fashion industry, Shen and $\mathrm{Li}[10]$ analyze the supply chain from a sustainable perspective. $\mathrm{Li}$ and Shen [11] study the sustainable design operations in the supply chain with an analytical model. Wiengarten et al. [12] study environmental investments and their impacts on operational performance using empirical data collected from a wide range of industries. The author found that dynamic industries such as apparel made fewer investments on supply chain environment practices. They also report that the environmental investments do not significantly improve the operational performance of dynamic industry. Lo et al. [13] investigate the impacts of the adoption of environment management systems on the financial performance of firms in the textile industry. They found a significant increase in ROA and ROS after the adoption of environment management systems. In our paper, we not only analyze financial ratios such as ROA, ROS, and SOA, but also study the firms' operational performance (e.g., inventory turnover, etc.). For more literature on social sustainable textile and apparel supply chain management, we recommend Köksal et al. [14] for reference.

Klassen and McLaughlin [15] analyze environment management and firm financial performance using firm-level data. They found a significant positive return for firms with environmental awards, and a significant negative return for firms which encounter environmental crisis. Jacobs et al. [16] investigate the environmental performance and the market value of firms. They found that the market does not react significantly to the aggregated categories of announcements about firms' corporate environmental initiatives (CEIs) and environmental awards and certifications (EACs). However, some subcategories of announcements are significant. Arora et al. [17] analyze the shareholder wealth effects of the appointments of corporate sustainable executives (CSEs). Based on their study of 106 announcements of CSE appointments, they found that the overall effect on the stock market is neutral. However, the stock market makes a significant positive response if the firm was faced with an adverse sustainability-related event in the year prior to the announcements, or if the appointed CSE has focused duties and responsibilities. Wu [18] studies the relationship between socially sustainable operations and the stock market reactions of firms in the textile and apparel industry in China. They found a negative link between them, and argue that it reflects the investors' worry about the cost related to the socially sustainable operations. $\mathrm{Li}$ and $\mathrm{Wu}$ [19] extend [18] and study the cross-industry stock market performance of socially sustainable operations of firms in China. All of these papers apply event study in their analysis. However, they focus on the stock market reaction. Our paper studies the long-term impact of the adoption of EMS on firms' financial and operational performance, which is different from the literature.

In this paper, we study firms' performance in profitability, sales, and operational efficiency after the adoption of EMS. We find that (i) textile and apparel firms in China experience a significant decrease in profitability and sales after EMS adoption; (ii) textile and apparel firms in China underwent a decrease in inventory productivity after EMS adoption. These results are different from previous research on EMS adoption for firms in the textile and apparel industry in the US, which report a positive return on assets and return on sales [13]. However, our findings are consistent with $\mathrm{Wu}$ [18] and $\mathrm{Li}$ and $\mathrm{Wu}$ [19], which report negative relationship between firms' socially sustainable operations and their stock market performance. We explain that the negative effects of EMS adoption on profitability and sales are the result of the costly investment in an environmentally-friendly manufacturing system and the losses in operational efficiency during the transition period.

The rest of the paper is organized as follows. The research hypotheses are developed in Section 2. We introduce the sampling process and data in Section 3. In Section 4, we describe the methodology and procedures of event study, which is used in this paper. Section 5 presents the results. We summarize our findings in Section 6, and point out the directions for future research. 


\section{Hypotheses}

The adoption of EMS brings both benefits and drawbacks to firm performance. In this work, we study the economic consequences of EMS adoption on firm's performance in profitability, sales, and operational efficiency. To be consistent with previous research $[13,20,21]$, we select return on assets (ROA, the ratio of operating income to total assets) as the performance measure for profitability. ROA represents the firm's ability to generate operating incomes with unit asset. Many Chinese textile and apparel firms act as manufacturers to serve their overseas clients. To fulfill the requirement of EMS, the firms have to raise investment to reshape their manufacturing processes and to improve their techniques, which leads to higher total assets. However, the firms' operating incomes cannot be easily increased in the short-term. This will cause a decrease in profitability after EMS adoption. So, our first hypothesis is stated as below.

\section{H1. Textile and apparel firms' ROA decrease after EMS adoption.}

We measure firms' performance in sales with sales over assets (SOA), which equals sales divided by the total assets. SOA measures the firm's sales generated from each unit of asset. Although better environmental performance helps a firm to shape a good public image as a socially responsible firm, it is not likely to increase the firm's sales soon after EMS adoption. Since it increases the firm's total assets, we expect the firm's SOA will decrease after EMS adoption. Our second hypothesis is stated as below.

\section{H2. Textile and apparel firms' SOA decrease after EMS adoption.}

To further explore the details of firm's performance in sales after EMS adoption, we propose another hypothesis, which uses sales as the performance measure.

\section{H2'. Textile and apparel firms' sales decrease after EMS adoption.}

Our last hypothesis is about the firm's operational efficiency. First, we use return on sales (ROS), which is the ratio of operating incomes on sales, to measure the cost efficiency [13]. ROS represents the operating incomes from unit sales. Note that sales can be broken down into operating incomes and operating expenses; a larger value of ROS indicates higher efficiency in cost management. EMS imposes constraints in the firm's manufacturing and operations processes, which introduces cost. Thus, we expect a decrease in a firm's ROS after EMS adoption.

\section{H3. Textile and apparel firms' ROS decrease after EMS adoption.}

Previous research shows that inventory profitability—which measures the firm's ability in effectively and efficiently managing inventory-is the key in producing shareholder wealth [22]. We use inventory turnover (the ratio of net sales over average inventory) to measure the firm's inventory productivity. It takes time for executives and employees to adapt to the newly adopted EMS, and thus inventory turnover will decrease after EMS adoption.

H3'. Textile and apparel firms' inventory turnover decrease after EMS adoption.

\section{Sample and Data}

In this work, we focus on firms in the textile and apparel industry in China. Our sample includes the announcements of firms' formal adoptions of EMS. These announcements are released by firms in their environmental reports and sustainability reports. We obtain the details of the announcements via the GTA-CSRR database.

To generate the sample, we first select firms whose core business is closely related to the textile and apparel industry in China. According to the Guidelines for the Industry Classification of Listed Companies (2012 Revision), we include all listed firms from the textile (CSRC code C17), textile and apparel (CSRC code C18), feather, fur, feathers and their products, and footwear industry (CSRC code C19), as well as chemical fiber manufacturing (CSRC code C28). Three B-shares stock 
and three shares carrying "ST" (special treatment) or "*ST" tags are excluded from the sample. Table 1 summarizes the statistics of the firms that are included in the sample. Among the 103 firms, 46 are listed on the Shenzhen Stock Exchange, while 57 are traded on the Shanghai Stock Exchange. Twenty-two firms announced the adoption of an environmental management system during 2008-2015. The 22 sample firms made 59 announcements during the period.

Table 1. Description of sample firms.

\begin{tabular}{cccc}
\hline Description & CSRC Code & No. of Firms & No. of Firms Adopting EMS \\
\hline Textile & C17 & 40 & 10 \\
Textile and apparel & C18 & 33 & 7 \\
Leather, fur, feathers and their products and footwear industry & C19 & 9 & 2 \\
Chemical fiber manufacturing & C28 & 21 & 3 \\
\hline Total & & 103 & 22 \\
\hline
\end{tabular}

Table 2 describes the performance measures of sample firms before and after the formal adoption of EMS. We observe that an average firm achieves growth in sales, total assets, and operating incomes. However, the ROA, ROS, SOA, and inventory turnover decrease. This is a symbol of loss in operational efficiency.

Table 2. Descriptive statistics for the adoption of environmental management systems (EMS).

\begin{tabular}{|c|c|c|c|c|c|c|c|c|c|}
\hline Performance Measures & \multicolumn{3}{|c|}{ Year -2 } & \multicolumn{3}{|c|}{ Year 0} & \multicolumn{3}{|c|}{ Year 1} \\
\hline ROA Operating & 2.6 & 2.2 & 2.3 & 1.8 & 1.3 & 1.6 & 1.2 & 0.6 & 2.5 \\
\hline SOA & 28.7 & 27.8 & 16.4 & 26.5 & 30.6 & 12.7 & 23.6 & 24.5 & 13.1 \\
\hline Sales & 632.2 & 306.5 & 738.0 & 835.3 & 485.8 & 727.4 & 892.8 & 498.4 & 860.7 \\
\hline Turnover & 206.6 & 173.9 & 175.5 & 179.6 & 117.0 & 213.3 & 176.5 & 134.0 & 208.4 \\
\hline
\end{tabular}

Sales, total assets, and operating incomes are stated in million yuan. Return on asset (ROA), return on sales (ROS), sales over asset (SOA), and inventory turnover are stated in \%.

\section{Methodology}

In this paper, we analyze the impacts of the adoption of EMS on the sample firms' performance in profitability, sales, and operational efficiency using event study. Event study identifies the causal links between events and firm performance by testing the significance of the abnormal value of certain variables against zero. Jacobs et al. [16] mention that event study has some advantages over other empirical research methods. We describe the procedures of event study used in this work below.

\section{(1) Define events}

We define the announcements of the formal adoption of EMS as events. We note that announcements of types of sustainable operations are often made on the same day. These announcements include the sample firms' operations which protects the benefits and interests of their shareholder, their employees, their supply chain partners, the general public, etc. [18]. However, there is no theoretical link between these operations and the sample firms' financial and operational performance in the long-term. Another observation is that a sample firm may disclose more than one event about the adoption of EMS. We exclude all subsequent announcements and only include the first in our sample. Finally, 22 EMS adoption events are identified.

We normalize the event year, in which the event of EMS adoption is announced, as year 0 . The years which are prior to year zero are defined as year -1 , year -2 , etc. The successive years after year 0 are labeled as year 1, year 2, etc. We follow Lo et al. [13] to set a three-year event window, 
which includes year -2 , year -1 , and year 1 . According to previous work [23], on average it costs a firm 6-18 months to prepare for the ISO 14000 certification. So, we set year -2 as the base year. The percentage changes in firms' sales, total assets, operating incomes, ROA, ROS, SOA, and inventory turnover are calculated for the event window.

(2) Generating the matched-pair control sample

To study the net effect of the adoption of an environmental management system, we need to control the firm-specified factors. We follow the literature $[13,20,24]$ and propose the following procedures to match the sample firm with control firms in year -2 .

Step one. We identify all firms which are classified in the manufacturing industry according to their CSRC code.

Step two. Firms that have no sufficient financial and operational performance data are excluded.

Step three. All sample firms which made an announcement about the adoption of EMS are removed.

Step four. Firms are matched according to the following matching rules. If a control firm is matched to a sample firm, we remove the control firm from the candidate list.

The above steps guarantee that a control firm will not be matched to multiple sample firms. The matching rule considers the firm's industry character, performance bounds, and the quality of data, and is described below.

Rule one. The control firm must have the same CSRC code as the sample firm. The CSRC code consists of an English letter and a two-digit number. Firms with the same CSRC code are classified in the same sub-industry.

Rule two. The release date of performance measures of the control firm in year -2 , year -1 , year 0 , and year 1 must fall in the \pm 3 -month band as the sample firm.

Rule three. The performance measures of the control firm must fall in the $\pm 10 \%$ band of the sample firm.

If more than one firm remains in the candidate list after the screening process, we pick the one whose performance measure is closest to the sample firm. If no control firm remains after screening using rule one, we skip it and directly move to rule two and rule three. If no control firm passes the screening of any rule, we remove the sample firm for this study. We report the matching results of the performance-industry matched group which passed the screening of rule one to rule three, and the performance-matched group which passed the screening of rule two and rule three.

(3) Estimate the abnormal value for performance measures

We define the abnormal performance with Equation (1). The superscripts $S$ and $C$ stand for sample firm and control firm. $P_{i t}^{M}$ is the percentage changes of the performance index $P$ for the $i$-th sample firm (if $M=S$, or matching firm if $M=C$ ) during the period from year -2 to year $t$. For a matched group of sample-control firm pairs, we first calculate $p_{i t}^{S}$ and $p_{i t}^{C}$ separately for all $i$ and $t=-1,0,1$. The abnormal value of a particular performance measure for a sample firm is defined as the difference in the percentage change between $p_{i t}^{S}$ and $p_{i t}^{C}$. The abnormal performance $A P_{i t}$ represents the net effect of EMS adoption for firm $i$ during the period from year -2 to year $t$, compared to the firm which does not adopt the EMS.

$$
A P_{i t}=P_{i t}^{S}-P_{i t}^{C}
$$

\section{(4) Testing statistics}

If the sample mean or median of abnormal value deviates from zero significantly, we identify a causal link between the event and the firm's performance. Thus, we can conclude that EMS adoption 
has a significant impact on the firm's financial and/or operational performance. We use $t$-test to examine the statistical significance of sample mean of abnormal performance.

The Student's $t$-test works well for normal populations or large samples. When dealing with small non-normal samples, the $t$-test is no longer appropriate. To guarantee the robustness of our results, we also report the results of the Wilcoxon signed-rank test and the generalized sign test.

\section{Results and Discussion}

\subsection{Profitability Performance}

We report the effects of EMS adoption on firms' ROA in Table 3. There are 7 and 12 firms, which are matched with control firms using the performance-industry and the performanceonly rule, respectively. The mean and median of the abnormal value of percentage changes in ROA are negative in most cases. During the three-year event window, the sample firms' mean and median ROA are $-26.99 \%$ and $-10.24 \%$ lower compared to the performance-industry matched control group. Only $42.86 \%$ of the sample firms' ROA are larger than the matching firms. However, the differences are not statistically significant. The results of the performance-only group are consistent with the performance-industry matched group. Both the mean and the median of the abnormal ROA are negative. We find that the mean and median of abnormal ROA are $-62.91 \%$ and $-64.94 \%$ for the performance-matched group, both of which are significant at the $10 \%$ level.

Table 3. Abnormal value of percentage changes in ROA.

\begin{tabular}{ccccccc}
\hline & \multicolumn{2}{c}{ Performance-Industry Matched Group (7 Obs) } & \multicolumn{2}{c}{ Performance Matched Group (12 Obs) } \\
\cline { 2 - 7 } & Year -2 to -1 & Year -2 to 0 & Year -2 to 1 & Year -2 to -1 & Year -2 to 0 & Year -2 to 1 \\
\hline Mean & $11.18 \%$ & $-15.45 \%$ & $-26.99 \%$ & $-19.61 \%$ & $-13.27 \%$ & $-62.91 \%$ \\
$t / z$ statistic & 0.39 & -0.36 & -0.59 & -0.54 & -0.43 & $-1.54 *$ \\
Median & $-7.81 \%$ & $-11.94 \%$ & $-10.24 \%$ & $-0.34 \%$ & $-2.84 \%$ & $-64.96 \%$ \\
$t / z$ statistic & 0.08 & -0.42 & -0.59 & -0.35 & -0.12 & $-1.37 *$ \\
$\%$ Positive & $42.86 \%$ & $42.86 \%$ & $42.86 \%$ & $50.00 \%$ & $50.00 \%$ & $41.67 \%$ \\
$t / z$ statistic & 0.00 & 0.00 & 0.00 & 0.29 & 0.29 & -0.29 \\
\hline
\end{tabular}

Table 4 summarizes the abnormal values in operating incomes for the sample firms. our firms are matched using the performance-industry rule, while 14 firms are matched using the performance-only rule. We observe positive abnormal operating incomes during year -2 to year -1 and year -2 to year 0 for both samples. The mean and median of abnormal operating incomes in the three-year event window are $28.98 \%$ and $61.32 \%$ for the performance-industry marched group. Seventy-five percent of the sample firms have positive abnormal operating incomes. However, none of the statics are significant. During the same period, the sample firms' mean and median abnormal operating incomes are $-224.44 \%$ and $-12.08 \%$ for the performance-matched sample. We observe that $71.43 \%$ of abnormal values are significantly positive during year -2 to year -1 and year -2 to 0 .

We conclude that the sample firm underwent a decrease in ROA, however there is no evidence supporting a decrease in operating incomes. So, the loss in profitability can be explained as a result of increasing total assets, which is shown in Table 7. 
Table 4. Abnormal value of percentage changes in operating income.

\begin{tabular}{ccccccc}
\hline & \multicolumn{2}{c}{ Performance-Industry Matched Group (4 Obs) } & \multicolumn{3}{c}{ Performance Matched Group (14 Obs) } \\
\cline { 2 - 7 } & Year -2 to -1 & Year -2 to 0 & Year -2 to 1 & Year -2 to -1 & Year -2 to 0 & Year -2 to 1 \\
\hline Mean & $0.35 \%$ & $36.44 \%$ & $28.98 \%$ & $127.10 \%$ & $36.44 \%$ & $-224.44 \%$ \\
$t / z$ statistic & 0.06 & 1.07 & 0.44 & 1.12 & 1.25 & -0.92 \\
Median & $-3.56 \%$ & $57.69 \%$ & $61.32 \%$ & $39.46 \%$ & $30.67 \%$ & $-12.08 \%$ \\
$t / z$ statistic & -0.18 & 0.91 & 0.18 & 1.13 & 1.13 & 0.00 \\
$\%$ Positive & $25.00 \%$ & $75.00 \%$ & $75.00 \%$ & $71.43 \%$ & $71.43 \%$ & $50.00 \%$ \\
$t / z$ statistic & -0.50 & 0.50 & 0.50 & $1.34 *$ & $1.34 *$ & 0.27 \\
\hline
\end{tabular}

* significant at the 0.10 level.

\subsection{Sales Performance}

There are 9 and 13 sample firms matched with control firms using the performance-industry and performance-only rules, respectively. In Table 5, we find that the results from the two samples are inconsistent. For the performance-industry matched group, the mean and median of abnormal SOA are negative for all cases. We observe significant negative abnormal SOA during the period from year -2 to year -1 . The mean and median loss in ROA are $28.17 \%$ and $34.22 \%$ respectively, which indicates loss in sales at the initial stage of EMS adoption. For the performance-matched group, we observe positive abnormal SOA for most cases; however, none of them are significant.

Table 5. Abnormal value of percentage changes in SOA.

\begin{tabular}{ccccccc}
\hline & \multicolumn{2}{c}{ Performance-Industry Matched Group (9 Obs) } & \multicolumn{3}{c}{ Performance Matched Group (13 Obs) } \\
\cline { 2 - 7 } & Year -2 to -1 & Year -2 to 0 & Year -2 to 1 & Year -2 to -1 & Year -2 to 0 & Year -2 to 1 \\
\hline Mean & $-28.17 \%$ & $-18.35 \%$ & $-36.21 \%$ & $9.09 \%$ & $2.07 \%$ & $-0.22 \%$ \\
$t / z$ statistic & $-2.43 * *$ & -1.04 & -0.95 & 0.94 & 0.17 & -0.02 \\
Median & $-34.22 \%$ & $-14.64 \%$ & $-8.81 \%$ & $7.51 \%$ & $17.29 \%$ & $17.93 \%$ \\
$t / z$ statistic & $-1.78 * *$ & -0.83 & -0.47 & 0.77 & 0.35 & 0.42 \\
$\%$ Positive & $33.33 \%$ & $44.44 \%$ & $33.33 \%$ & $61.54 \%$ & $53.85 \%$ & $53.85 \%$ \\
$t / z$ statistic & -0.67 & 0.00 & -0.67 & 0.55 & 0.00 & 0.00 \\
\hline
\end{tabular}

To further explore the reasons for the decrease in SOA after EMS adoption, we analyze the effects of EMS adoption on the sample firms' sales and total assets. We first report the results for the abnormal sales. There are 11 and 18 sample firms matched with control firms using the performance-industry and performance-only rules, respectively. As is displayed in Table 6, for the performance-industry matched group, the abnormal sales are negative for the period from year -2 to year -1 , and year -2 to year 1 . The median of abnormal sales is $6.24 \%$ during year -2 to year -1 , which is significant at the $10 \%$ level. However, the results for the performance-matched group indicate significant positive abnormal sales for the period from year -2 to year -1 , and year -2 to year 0 . The inconsistence of results between the two samples is due to the different rules in finding the matching firms, since the firms in different industries have different patterns in the dynamics of sales. The result from the performance-industry matched group works better in explaining the abnormal sales.

Table 7 shows that the mean and median of the abnormal value changes in total assets are all significantly positive for the performance-industry matched group. There are 11 firms matched using the performance-industry matching rule. The mean and median of abnormal total assets are $15.35 \%$ and $16.18 \%$ for the period from year -2 to year $-1,93.57 \%$ and $33.91 \%$ for the period from year -2 to year 0 , and $118.87 \%$ and $48.86 \%$ for the period from year -2 to year 1 . There are $72.73 \%, 81.82 \%$, and $81.82 \%$ of abnormal total assets of the sample firms that are positive for the three periods. We can observe a significant and steady trend of increasing abnormal total assets. The result from the 
performance-matched group is consistent with the one from the performance-industry matched group, but the result is less significant.

Table 6. Abnormal value of percentage changes in sales.

\begin{tabular}{ccccccc}
\hline & \multicolumn{2}{c}{ Performance-Industry Matched Group (11 Obs) } & \multicolumn{3}{c}{ Performance Matched Group (18 Obs) } \\
\cline { 2 - 7 } & Year -2 to -1 & Year -2 to 0 & Year -2 to 1 & Year -2 to -1 & Year -2 to 0 & Year -2 to 1 \\
\hline Mean & $-13.10 \%$ & $-8.43 \%$ & $-14.90 \%$ & $22.78 \%$ & $62.11 \%$ & $46.62 \%$ \\
$t / z$ statistic & -1.24 & -0.43 & -0.63 & $1.55 *$ & $1.82 * *$ & 1.00 \\
Median & $-6.24 \%$ & $10.26 \%$ & $-6.66 \%$ & $11.19 \%$ & $11.08 \%$ & $6.64 \%$ \\
$t / z$ statistic & $-1.29 *$ & 0.22 & -0.40 & 1.26 & $1.70 * *$ & 0.57 \\
$\%$ Positive & $36.36 \%$ & $63.64 \%$ & $45.45 \%$ & $61.11 \%$ & $61.11 \%$ & $55.56 \%$ \\
$t / z$ statistic & -0.60 & 0.60 & 0.00 & 0.71 & 0.71 & 0.24 \\
\hline
\end{tabular}

${ }^{* *}$ significant at the 0.05 level; ${ }^{*}$ significant at the 0.10 level.

Table 7. Abnormal value of percentage changes in total assets.

\begin{tabular}{|c|c|c|c|c|c|c|}
\hline & \multicolumn{3}{|c|}{ Performance-Industry Matched Group (11 Obs) } & \multicolumn{3}{|c|}{ Performance Matched Group (18 Obs) } \\
\hline & Year -2 to -1 & Year -2 to 0 & Year -2 to 1 & B & Year -2 to 0 & Year -2 to 1 \\
\hline Mean & $15.35 \%$ & $93.57 \%$ & $118.87 \%$ & $-66.93 \%$ & $-57.52 \%$ & $-90.70 \%$ \\
\hline$t / z$ statistic & $1.89^{* *}$ & 1.44 * & 1.48 * & -0.84 & -0.47 & -0.63 \\
\hline Median & $16.18 \%$ & $33.91 \%$ & $48.86 \%$ & $2.35 \%$ & $8.68 \%$ & $6.28 \%$ \\
\hline$t / z$ statistic & $1.56^{*}$ & $2.27^{* *}$ & $2.45^{* * *}$ & 0.65 & 1.44 * & 0.00 \\
\hline \% Positive & $72.73 \%$ & $81.82 \%$ & $81.82 \%$ & $55.56 \%$ & $66.67 \%$ & $55.56 \%$ \\
\hline$t / z$ statistic & 1.21 & $1.81^{* *}$ & $1.81^{* *}$ & 0.24 & 1.18 & 0.24 \\
\hline
\end{tabular}

To summarize, the sample firms experienced a significant decrease in SOA during the first year of EMS adoption. Our analysis shows that it is caused by the joint effects of decrease in sales and increase in total assets.

\subsection{Operational Efficiency Performance}

Table 8 summarizes the results for abnormal ROS. Using the performance-industry matching rule, there are eight sample firms which are matched with control firms. We observe that both the mean and median of the abnormal ROS are positive for all three periods. The portion of positive abnormal ROS are less than $40 \%$ for the periods from year -2 to year 0 , and year -2 to year 1 . Similar results are obtained for the performance-matched group. However, none of the statistics is significant.

Table 8. Abnormal value of percentage changes in ROS.

\begin{tabular}{ccccccc}
\hline & \multicolumn{2}{c}{ Performance-Industry Matched Group (8 Obs) } & \multicolumn{3}{c}{ Performance Matched Group (12 Obs) } \\
\cline { 2 - 6 } & Year -2 to -1 & Year -2 to 0 & Year -2 to 1 & Year -2 to -1 & Year -2 to 0 & Year -2 to 1 \\
\hline Mean & $38.29 \%$ & $21.11 \%$ & $12.25 \%$ & $-3.42 \%$ & $-0.08 \%$ & $-4.11 \%$ \\
$t / z$ statistic & 0.81 & 0.61 & 0.17 & -0.11 & -0.00 & -0.09 \\
Median & $1.50 \%$ & $-10.56 \%$ & $-13.93 \%$ & $-1.81 \%$ & $-21.82 \%$ & $-23.72 \%$ \\
$t / z$ statistic & 0.49 & -0.07 & -0.35 & 0.04 & 0.04 & -0.12 \\
$\%$ Positive & $50.00 \%$ & $37.50 \%$ & $37.50 \%$ & $50.00 \%$ & $41.67 \%$ & $41.67 \%$ \\
$t / z$ statistic & 0.35 & -0.35 & -0.35 & 0.29 & -0.29 & -0.29 \\
\hline
\end{tabular}

Our last result proves a decrease in inventory productivity after EMS adoption. As stated in Table 9, we find eight sample firms which are matched with control firms using the performance-industry rule. The firms experienced decreases in inventory turnover during the first two years after EMS adoption. The mean and median of abnormal inventory turnover are $-14.49 \%$ 
and $-10.17 \%$ for the period from year -2 to year 0 . During the same period, only $12.50 \%$ of abnormal inventory turnover is positive. These results are significant. Although we observe positive mean abnormal inventory turnover during the period from year -2 to year 1 (indicating an increase in inventory productivity in year 1), the result is statistically insignificant. The abnormal inventory turnover is sharper if the performance-matched group is considered. The mean abnormal value for year -2 to year -1 and year -2 to year 0 reached $-12.10 \%$ and $-27.84 \%$. The median abnormal value is $-14.19 \%$ for the period of year -2 to year 0 . The decrease in mean and median of inventory turnover during the period from year -2 to year 0 are significant at the $10 \%$ level.

Table 9. Abnormal value of percentage changes in inventory turnover.

\begin{tabular}{ccccccc}
\hline & \multicolumn{2}{c}{ Performance-Industry Matched Group (8 Obs) } & \multicolumn{3}{c}{ Performance Matched Group (13 Obs) } \\
\cline { 2 - 7 } & Year -2 to -1 & Year -2 to 0 & Year -2 to 1 & Year -2 to -1 & Year -2 to 0 & Year -2 to 1 \\
\hline Mean & $-12.70 \%$ & $-14.49 \%$ & $2.72 \%$ & $-12.10 \%$ & $-27.84 \%$ & $-12.29 \%$ \\
$t / z$ statistic & -1.21 & $-1.43 *$ & 0.25 & $-1.45 *$ & $-1.71 *$ & -0.71 \\
Median & $-6.04 \%$ & $-10.17 \%$ & $1.44 \%$ & $-6.31 \%$ & $-14.19 \%$ & $-23.81 \%$ \\
$t / z$ statistic & -0.91 & $-1.61 *$ & 0.21 & -0.91 & $-1.33 *$ & -0.63 \\
$\%$ Positive & $50.00 \%$ & $12.50 \%$ & $50.00 \%$ & $46.15 \%$ & $38.46 \%$ & $46.15 \%$ \\
$t / z$ statistic & 0.35 & $-1.77^{* *}$ & 0.35 & 0.00 & -0.55 & 0.00 \\
\hline
\end{tabular}

\subsection{Discussion}

Our empirical results prove that the sample firms experienced significant decrease in ROA and SOA during the event window. Our result of abnormal sales and total assets show that the decrease in ROA is caused by the increase in total assets, while the decrease in SOA is due to the joint effects of a decrease in sales and an increase in total assets. This is evidence that the textile and apparel firms underwent decrease in profitability and sales after EMS adoption. We also observe significant decreases in inventory turnover, which indicates loss of inventory productivity during the process of adopting and transiting to the EMS. We study the sample firms' abnormal ROS, which measures the cost efficiency of the sample firms. However, none of the statistics is significant. It worth mentioning that the results from the performance-industry matched group and the performance-matched group are inconsistent for the abnormal values of SOA, ROS, sales, and total assets. Noting that firms in different industries perform differently in profitability, sales, etc., we suggest that the results obtained from the performance-industry matched group works better in explaining the changes in the corresponding performance measure.

Our results are different from [13], which reports a positive abnormal value of ROA and ROS after EMS adoption using financial data from US listed firms. One reason for the difference is that the Chinese manufacturers are at the end of the global textile and apparel value chain. The firms adopt EMS passively due to the regulatory authority or the pressure of supply chain partners. On the one hand, the implementation of EMS requires investments in environmentally-friendly manufacturing systems and equipment which leads to the increase of total assets. On the other hand, during the process of transitioning to the new manufacturing process and system, the firms lose operational efficiency. These negative effects dominate the benefit (e.g., cost reduction, innovation, etc.) which is caused by the adoption of EMS. To mitigate the risk during the process of EMS adoption, firms are suggested to provide training to their executives and employees to guarantee smooth transition to the new EMS, which may help to reduce the loss in productivity and operational efficiency.

There are several limitations related to our results. First of all, the sample size is relatively small. So, the classical Student's $t$-test for the mean of abnormal performance measure is not robust. Our results rely heavily on the non-parametric rank-based tests for the median and percent of positive abnormal measures. Second, we do not control the firm size in this work. As suggested in literature [13,24], firm size could affect firm performance. However, the small sample size makes it impossible to add 
requirements in firm size to the matching rule. Otherwise, more firms would not be able to match to a control firm. Third, we do not consider the medium- and long-term abnormal performance after EMS adoption. In theory, adopting EMS may improve a firm's performance in sales and profitability in the long run. We expect to see positive abnormal performance in profitability, sales, and operational efficiency after the formal adoption of EMS. However, more than half of the EMS adoptions in our sample happened after 2014. Analyzing long-run abnormal performances will further reduce the sample size. For the same reason, we are not able to study the effects of regulation changes and public concern in environmental problems on the abnormal performance.

\section{Summary}

In this work, we study the effect of EMS adoption on the operational performance of firms in the textile and apparel industry of China. We analyze the sample firms' performances in profitability, sales, and operational efficiency using event study. We match the sample firms using the performance-industry rule and the performance rule separately. Our results prove that the sample firms experienced significant decreases in ROA and SOA during the event window. Our results of abnormal sales and total assets show that the decrease in ROA is caused by the increase in total assets, while the decrease in SOA is due to the joint effects of decrease in sales and increase in total assets. This is evidence that the textile and apparel firms underwent decrease in profitability and sales after EMS adoption. We also observe significant decreases in inventory turnover, which indicates loss of inventory productivity during the process of adopting and transitioning to the EMS. Our results are consistent with the study on the relationship between socially sustainable operation and stock market return in China [18]. This explains why investors react negatively to firms' socially sustainable performance. We explain that the loss in profitability and sales after EMS adoption is a result of the huge investment in environmentally-friendly manufacturing systems as well as the loss in operational efficiency during the transition process.

In this work, the sample size is relatively small, which results in several limitations to the work. First, we do not control firm size in this work. Second, we do not consider the medium- and long-term abnormal performance after EMS adoption. Last, we do not study the effects of regulation changes and public concern in environmental problems on the abnormal performance. All of the above points are interesting directions for future study when more data is available.

Acknowledgments: We thank the two anonymous reviewers and the academic editor for their comments, which help us improve the paper. Biao is supported by "the Fundamental Research Funds for the Central Universities (2017)", and "the Innovative Research Team Project: Financial Risk Management" provided by the Zhongnan University of Economics and Law. Kekun is supported by the Start-Up Grant (31541410505) and the General Research Grand (31541310516) from the Zhongnan University of Economics and Law.

Author Contributions: Biao Li and Kekun Wu design the study. Biao Li is responsible to data collection and statistical method. Kekun $\mathrm{Wu}$ analyzed the data and wrote the entire manuscript. All authors read and approved the final manuscript for submission.

Conflicts of Interest: The authors declare no conflict of interest.

\section{References}

1. Bhat, V.N. Does it pay to be green? Int. J. Environ. Stud. 1999, 56, 497-507.

2. King, A.A.; Lenox, M.J. Does it really pay to be green? An empirical study of firm environmental and financial performance. J. Ind. Ecol. 2001, 5, 105-116.

3. Chen, H.L.; Burns, L.D. Environmental analysis of textile products. Cloth. Text. Res. J. 2006, 24, $248-261$.

4. China Statistical Yearbook 2016. Available online: http://www.stats.gov.cn/tjsj/ndsj/2016/indexeh.htm (accessed on 4 December 2016).

5. World Trade Statistical Review 2016. World Trade Organization 2016. Available online: https://www.wto. org/english/res_e/statis_e/wts2016_e/wts16_toc_e.htm (accessed on 4 December 2016). 
6. Ma, J.; Wang, J.; Collins, M.; Wu, M.; Orlins, S.; Li, J. Textile Phase II Report-Sustainable Apparel's Critical Blindspot. Available online: http://wwwen.ipe.org.cn/reports/NewsReport.aspx (accessed on 4 December 2017).

7. Kleindorfer, P.R.; Singhal, K.; Wassenhove, L.N. Sustainable operations management. Prod. Oper. Manag. 2005, 14, 482-492.

8. Drake, D.F.; Spinler, S. OM Forum-Sustainable Operations Management: An Enduring Stream or a Passing Fancy? Manuf. Serv. Oper. Manag. 2013, 15, 689-700.

9. Shen, B. Sustainable fashion supply chain: Lessons from H\&M. Sustainability 2014, 6, 6236-6249.

10. Shen, B.; Li, Q.Y. Impacts of Returning Unsold Products in Retail Outsourcing Fashion Supply Chain: A Sustainability Analysis. Sustainability 2015, 7, 1172-1185.

11. Li, Q.; Shen, B. Sustainable Design Operations in the Supply Chain: Non-profit Manufacturer v.s. For-profit Manufacturer. Sustainability 2016, 8, 639.

12. Wiengarten, F.; Pagell, M.; Fynes, B. Supply chain environmental investments in dynamic industries: Comparing investment and performance differences with static industries. Int. J. Prod. Econ. 2012, 135, 541-551.

13. Lo, C.K.; Yeung, A.C.; Cheng, T.C. The impact of environmental management systems on financial performance in fashion and textiles industries. Int. J. Prod. Econ. 2012, 135, 561-567.

14. Köksal, D.; Strähle, J.; Müller, M.; Freise, M. Social Sustainable Supply Chain Management in the Textile and Apparel Industry-A Literature Review. Sustainability 2017, 9, 100.

15. Klassen, R.D.; McLaughlin, C.P. The impact of environmental management on firm performance. Manag. Sci. 1996, 42, 1199-1214.

16. Jacobs, B.W.; Singhal, V.R.; Subramanian, R. An empirical investigation of environmental performance and the market value of the firm. J. Oper. Manag. 2010, 28, 430-441.

17. Arora, P.; Hora, M.; Singhal, V.; Subramanian, R. When do Appointments of Corporate Sustainability Executives affect Shareholder Value?. (28 March 2017). Georgia Tech Scheller College of Business Research Paper No. 17-17. Available online: https://www.scheller.gatech.edu/directory/phd/arora/ pubs/CSEAppointments_Final.pdf (accessed on 8 June 2017).

18. Wu, K. Social Sustainable Performance and the Market Value of the Firm in Textile and Apparel Industry of China. Unpublished work, 2017.

19. Li, B.; Wu, K. The Price of Environmental Sustainability: Empirical Evidence from Stock Market Performance. Unpublished work, 2017.

20. Hendricks, K.B.; Singhal, V.R. Association between supply chain glitches and operating performance. Manag. Sci. 2005, 51, 695-711.

21. Hendricks, K.B.; Singhal, V.R. The effect of product introduction delays on operating performance. Manag. Sci. 2008, 54, 878-892.

22. Alan, Y.; Gao, G.P.; Gaur, V. Does inventory productivity predict future stock returns? A retailing industry perspective. Manag. Sci. 2014, 60, 2416-2434.

23. Corbett, C.J.; Montes-Sancho, M.J.; Kirsch, D.A. The financial impact of ISO 9000 certification in the United States: An empirical analysis. Manag. Sci. 2005, 51, 1046-1059.

24. Barber, B.M.; Lyon, J.D. Detecting abnormal operating performance: The empirical power and specification of test statistics. J. Financ. Econ. 1996, 41, 359-399.

(C) 2017 by the authors. Licensee MDPI, Basel, Switzerland. This article is an open access article distributed under the terms and conditions of the Creative Commons Attribution (CC BY) license (http:/ / creativecommons.org/licenses/by/4.0/). 